\title{
Thorium(IV) alkyl synthesis from a thorium(III) cyclopentadienyl complex and an Nheterocyclic olefin
}

DOI:

10.1016/j.jorganchem.2017.08.015

\section{Document Version}

Accepted author manuscript

Link to publication record in Manchester Research Explorer

\section{Citation for published version (APA):}

Liu, J., Seed, J., Formanuik, A., Ortu, F., Wooles, A., Mills, D., \& Liddle, S. (2017). Thorium(IV) alkyl synthesis from a thorium(III) cyclopentadienyl complex and an Nheterocyclic olefin. Journal of Organometallic Chemistry. https://doi.org/10.1016/j.jorganchem.2017.08.015

\section{Published in:}

Journal of Organometallic Chemistry

\section{Citing this paper}

Please note that where the full-text provided on Manchester Research Explorer is the Author Accepted Manuscript or Proof version this may differ from the final Published version. If citing, it is advised that you check and use the publisher's definitive version.

\section{General rights}

Copyright and moral rights for the publications made accessible in the Research Explorer are retained by the authors and/or other copyright owners and it is a condition of accessing publications that users recognise and abide by the legal requirements associated with these rights.

\section{Takedown policy}

If you believe that this document breaches copyright please refer to the University of Manchester's Takedown Procedures [http://man.ac.uk/04Y6Bo] or contact uml.scholarlycommunications@manchester.ac.uk providing relevant details, so we can investigate your claim.

\section{OPEN ACCESS}


- Submission to JOMC William J. Evans Lanthanide and Actinide Complexes Issue -

Thorium(IV) alkyl synthesis from a thorium(III) cyclopentadienyl complex and an $N$ heterocyclic olefin

Jingjing Liu, John A. Seed, Alasdair Formanuik, Fabrizio Ortu, Ashley J. Wooles, David P. Mills, ${ }^{*}$ and Stephen T. Liddle*

School of Chemistry, The University of Manchester, Oxford Road, Manchester, M13 9PL, U.K.

*Corresponding author.

E-mail address: $\quad$ steve.liddle@manchester.ac.uk (S.T. Liddle);

david.mills@manchester.ac.uk (D.P.Mills)

Keywords: thorium, cyclopentadienyl, $N$-heterocyclic olefin, methyl, alkylidene. 


\section{ABSTRACT}

Treatment of the tris(cyclopentadienyl) thorium(III) complex $\left[\mathrm{Th}\left(\eta^{5}-\mathrm{Cp}^{\prime \prime}\right)_{3}\right]\left[\mathbf{1}, \mathrm{Cp}^{\prime \prime}=\mathrm{C}_{5} \mathrm{H}_{3}-1,3-\right.$ $\left.\left(\mathrm{SiMe}_{3}\right)_{2}\right]$ with the $N$-heterocyclic olefin $\mathrm{H}_{2} \mathrm{C}=\mathrm{C}(\mathrm{NMeCH})_{2}$ (2) reproducibly produces the thorium(IV)-methyl derivative $\left[\mathrm{Th}\left(\eta^{5}-\mathrm{Cp}^{\prime \prime}\right)_{3}(\mathrm{Me})\right]$ (3) along with $\mathrm{MeImCH} \mathrm{CH}_{2} \operatorname{ImMe}(\operatorname{Im}=$ imidazole). The reaction mechanism, which is consistent with ${ }^{1} \mathrm{H}$ NMR spectroscopic observations, is proposed to proceed via: (i) coordination of $\mathbf{2}$ to $\mathbf{1}$; (ii) one-electron transfer from thorium to $\mathbf{2}$; (iii) $\mathrm{N}$-methyl cleavage and transfer to thorium to give 3; (iv) coupling of the resulting imidazolium radical by-product to give $\mathrm{MeImCH} \mathrm{CH}_{2} \mathrm{ImMe}$. Complex 3 has been characterised by single crystal X-ray diffraction, multi-nuclear NMR and IR spectroscopies, and elemental analyses, and MeImCH ${ }_{2} \mathrm{CH}_{2} \operatorname{ImMe}$ by ${ }^{1} \mathrm{H}$ NMR spectroscopy and mass spectrometry.

\section{Introduction}

Compared to extensive investigations spanning decades regarding transition metal carbene complexes, related studies in the actinide series remain relatively rare [1-6]. After Gilje's seminal report of the tris(cyclopentadienyl) uranium-carbene complex, $\left[\mathrm{U}\left(\eta^{5}-\mathrm{Cp}\right)_{3}\left(\mathrm{CHPMe}{ }_{2} \mathrm{Ph}\right)\right](\mathbf{I}$, Figure 1) [7], and some related reactivity studies [8-16], the area fell into abeyance for over 25 years. The field was revived in the late 2000s, principally through studies on uranium and thorium with the application of pincer carbenes with two phosphanyl-substituents and some mono-phosphanyl variants with amide co-ligands [17-36]. It is notable, however, that all uranium- and thoriumcarbenes prepared on macroscopic scales reported to date exhibit at least one or, more usually, two phosphanyl-substituents. For both uranium and thorium the only examples of 'true' or 'pure' alkylidene species, that is where the carbene $\alpha$-substituents are hydrogen or alkyl groups, remain restricted to cryogenic matrix isolation studies, where compounds are prepared on microscopic scales, or are proposed as reaction intermediates [37-48]. 


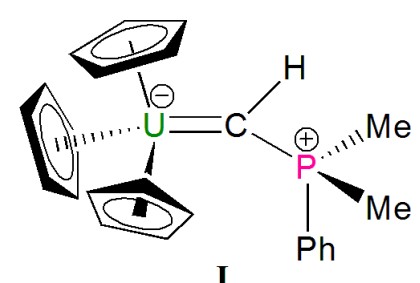

Figure 1. Structure of $\left[\mathrm{U}\left(\eta^{5}-\mathrm{Cp}\right)_{3}\left(\mathrm{CHPMe}_{2} \mathrm{Ph}\right)\right](\mathbf{I})$.

In order to progress the area away from phosphanyl-substituted carbenes towards 'true' alkylidenes, we became interested in probing the coordination and organometallic chemistry of $N$-heterocyclic olefins (NHOs) of the general form $\mathrm{H}_{2} \mathrm{C}=\mathrm{C}(\mathrm{NRCH})_{2}$ [49]. The methylene groups of NHOs are known to be basic and nucleophilic, and so might be expected to coordinate to electron deficient metals such as thorium. In that scenario, a number of electronic structure formulations can be used to depict the methylene-metal and methylene-imidazole (Im) interactions, and thus such a derivative could be formally regarded to possess some alkylidene character [50] where the alkylidene is protected by a $N$-heterocyclic carbene (NHC), rather than viewing the methylene-Im unit as an NHO, Figure 2.

(a)

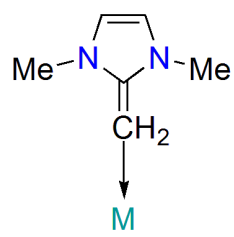

(b)<smiles></smiles>

(c)<smiles></smiles>

Figure 2. Various representations of potential bonding scenarios of a NHO to a metal emphasising (a) NHO and (b) and (c) methylene/alkylidene-type motifs. Form (c) could be considered to represent a singlet methylidene fragment stabilised by donation from the now formal NHC and/or the metal. 
Noting the prior success of Gilje's complex I which contains a tris(cyclopentadienyl)uranium component, ${ }^{7}$ we turned our attention to investigating the coordination chemistry of the closely related, but inherently more reactive, thorium(III) tris(cyclopentadienyl) complex $\left[\mathrm{Th}\left(\eta^{5}-\mathrm{Cp}^{\prime \prime}\right)_{3}\right][\mathbf{1}$, $\left.\mathrm{Cp}^{\prime \prime}=\mathrm{C}_{5} \mathrm{H}_{3}-1,3-\left(\mathrm{SiMe}_{3}\right)_{2}\right]$ [51] with a sterically unencumbered $\mathrm{NHO}$ with $N$-methyl groups, $\mathrm{H}_{2} \mathrm{C}=\mathrm{C}(\mathrm{NMeCH})_{2}$ (2) [52]. Complex 1 is one of a exceptionally small number of thorium(III) complexes [51,53-60], and has the most well-developed reactivity profile to date [54,61-64]. Although we anticipated formation of the methylene adduct $\left[\mathrm{Th}\left(\eta^{5}-\mathrm{Cp}^{\prime \prime}\right)_{3}\left\{\mathrm{H}_{2} \mathrm{C}=\mathrm{C}(\mathrm{NMeCH})_{2}\right\}\right]$ (II), we report herein that the isolated thorium-containing product from this reaction is instead the thorium(IV)-methyl derivative $\left[\mathrm{Th}\left(\eta^{5}-\mathrm{Cp}^{\prime \prime}\right)_{3}(\mathrm{Me})\right](\mathbf{3})$. The reaction is proposed to proceed via formation of II in solution and one electron transfer from $\mathbf{1}$ to $\mathbf{2}$. This results in $N$-methyl cleavage and transfer to thorium to give $\mathbf{3}$ and coupling of the imidazolium radical by-product to give MeImCH $\mathrm{CH}_{2} \mathrm{ImMe}$. This proposal is consistent with observations from ${ }^{1} \mathrm{H}$ NMR spectroscopic monitoring of the reaction.

\section{Experimental}

\subsection{General methods}

All syntheses and manipulations were conducted under argon with rigorous exclusion of oxygen and water using Schlenk line and glove box techniques. Toluene was sparged with argon, passed through columns containing Q-5 and molecular sieves, stored over a potassium mirror and degassed before use. $\mathrm{C}_{6} \mathrm{D}_{6}$ was dried by refluxing over $\mathrm{K}$ and was vacuum transferred and degassed by three freeze-pump-thaw cycles before use. [Th( $\left(\eta^{5}-\mathrm{Cp}^{\prime \prime}\right)_{3}$ ] (1) [51] and $\mathrm{CH}_{2}=\mathrm{C}(\mathrm{NMeCH})_{2}$ (2) [52] were prepared according to literature methods. ${ }^{1} \mathrm{H}(400.1 \mathrm{MHz}),{ }^{13} \mathrm{C}\left\{{ }^{1} \mathrm{H}\right\}(100.3 \mathrm{MHz})$ and ${ }^{29} \mathrm{Si}\left\{{ }^{1} \mathrm{H}\right\}(79$ MHz) NMR spectra were obtained on an Avance III $400 \mathrm{MHz}$ spectrometer at $298 \mathrm{~K}$, unless otherwise stated. These were referenced to the solvent used, or to external TMS $\left({ }^{1} \mathrm{H},{ }^{13} \mathrm{C},{ }^{29} \mathrm{Si}\right)$. Fourier transform infrared spectra were recorded as Nujol mulls in $\mathrm{KBr}$ discs using a Shimadzu 
IRAffinity-1S spectrometer. Elemental analyses were performed by Mrs Anne Davies and $\mathrm{Mr}$ Martin Jennings at The University of Manchester, U.K.

\subsection{Synthesis of $\left[T h\left(\eta^{5}-C p^{\prime \prime}\right)_{3}(M e)\right](3)$}

A Schlenk flask was charged with $1(0.75 \mathrm{~g} .0 .87 \mathrm{mmol})$ and $2(0.10 \mathrm{~g}, 0.87 \mathrm{mmol})$. The mixture was dissolved in $20 \mathrm{ml}$ toluene. The reaction mixture was refluxed at $130{ }^{\circ} \mathrm{C}$ for 18 hours, during which time the blue colour changed to green-brown, and following cooling was concentrated to 2 ml. Colourless crystals of $\mathbf{3}$ formed at room temperature from this dark brown solution $(0.21 \mathrm{~g}$, 0.25 mmol, $28 \%$ ). Anal calcd (\%) for $\mathrm{C}_{34} \mathrm{H}_{66} \mathrm{Si}_{6} \mathrm{Th}: \mathrm{C}, 46.66 ; \mathrm{H}, 7.61$. Found (\%): C, 45.13; H, 7.62. Low carbon values were obtained reproducibly; we attribute this to carbide formation, a common occurrence in silicon-rich organometallics, including specific examples of f-element $\mathrm{Cp}^{\prime \prime}$ complexes [65]. ${ }^{1} \mathrm{H}$ NMR $\left(\mathrm{C}_{6} \mathrm{D}_{6}, 298 \mathrm{~K}, 400.1 \mathrm{MHz}\right): \delta=6.65(\mathrm{~m}, 6 \mathrm{H}, \mathrm{Cp}-H), 6.56(\mathrm{~m}, 3 \mathrm{H}, \mathrm{Cp}-H)$, $1.02\left(\mathrm{~s}, 3 \mathrm{H}, \mathrm{CH}_{3}\right), 0.40\left(\mathrm{~s}, 54 \mathrm{H}, \mathrm{Si}\left(\mathrm{CH}_{3}\right)_{3}\right) .{ }^{13} \mathrm{C}\left\{{ }^{1} \mathrm{H}\right\}$ NMR $\left(\mathrm{C}_{6} \mathrm{D}_{6}, 298 \mathrm{~K}, 100.6 \mathrm{MHz}\right): \delta=132.53$ (C-Cp ring), 132.33 ( $\mathrm{CH}-\mathrm{Cp}$ ring), 127.37 ( $\mathrm{CH}-\mathrm{Cp}$ ring), $39.21\left(\mathrm{Th}-\mathrm{CH}_{3}\right), 1.69\left(\mathrm{Si}\left(\mathrm{CH}_{3}\right)_{3}\right)$. ${ }^{29} \mathrm{Si}\left\{{ }^{1} \mathrm{H}\right\}$ NMR $\left(\mathrm{C}_{6} \mathrm{D}_{6}, 296.5 \mathrm{~K}, 79.5 \mathrm{MHz}\right): \delta=-8.34\left(\mathrm{Si}\left(\mathrm{CH}_{3}\right)_{3}\right)$. FTIR (Nujol): $\tilde{v}=1560(\mathrm{w}), 1080$ (br, s), $922(\mathrm{w}), 835(\mathrm{~s}), 754(\mathrm{~m}), 689(\mathrm{~m}) \mathrm{cm}^{-1}$.

\subsection{X-ray crystallography}

Selected bond lengths and angles for $\mathbf{3}$ are compiled in Table 1 and crystal data are compiled in Table 2. A crystal of $\mathbf{3}$ was examined using an Agilent Supernova diffractometer, equipped with CCD area detector and mirror-monochromated Mo K $\alpha$ radiation $(\lambda=0.71073 \AA)$. Cell parameters were refined from the observed positions of all strong reflections in each data set. A Gaussian grid face-indexed was applied [66]. The structure was solved by direct methods using SHELXS [67] and the dataset was refined by full-matrix least-squares on all unique $F^{2}$ values, with anisotropic 
displacement parameters for all non-hydrogen atoms, and with constrained riding hydrogen geometries; $U_{\text {iso }}(\mathrm{H})$ was set at 1.2 (1.5 for methyl groups) times $U_{\text {eq }}$ of the parent atom. The largest features in final difference syntheses were close to heavy atoms and were of no chemical significance. CrysAlisPro [68] was used for control and integration, and SHELX [67] and OLEX2 [69] were employed for structure solution and refinement. ORTEP-3 [70] and POV-Ray [71] were employed for molecular graphics. CCDC 1560927 contains the supplementary crystal data for this article. These data can be obtained free of charge from the Cambridge Crystallographic Data Centre via www.ccdc.cam.ac.uk/data_request/cif.

\section{Results and discussion}

\subsection{Synthesis and spectroscopic characterisation of $\left[T h\left(\eta^{5}-C p^{\prime \prime}\right)_{3}(\mathrm{Me})\right](3)$}

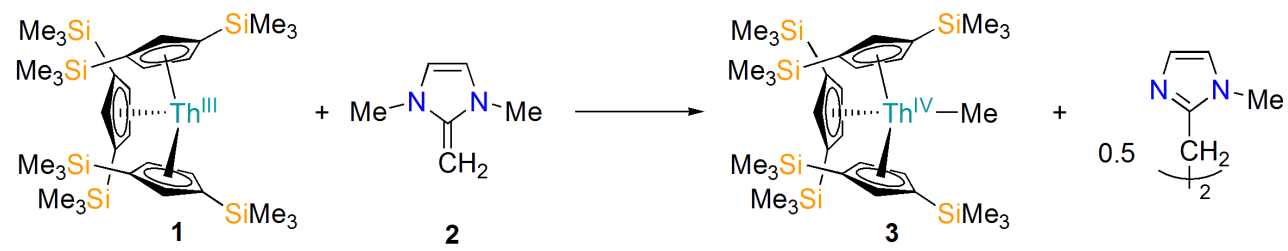

Scheme 1. Synthesis of 3 from 1 and 2. Conditions: toluene, reflux.

Stirring a mixture of $\mathbf{1}$ and $\mathbf{2}$ in toluene results in retention of the characteristic blue colour of $\mathbf{1}$ and no reaction seemingly occurs over a 24 hour stir. We therefore refluxed a solution of $\mathbf{1}$ and $\mathbf{2}$ in toluene for 18 hours, and during that time the blue solution changed to a green-brown colour. Following cooling, colourless crystals of $\mathbf{3}$, isolated in $28 \%$ yield, grew at room temperature, Scheme 1. The ${ }^{1} \mathrm{H}$ NMR spectrum of crystalline 3 dissolved in $\mathrm{D}_{6}$-benzene exhibits the anticipated pattern of 54:6:3 hydrogens reflecting the $\mathrm{SiMe}_{3}$, and two $\mathrm{Cp}-\mathrm{H}$ environments, in addition to a resonance at $1.02 \mathrm{ppm}$ that integrates as 3 hydrogens for the newly formed methyl group. The methyl carbon resonates at $39.2 \mathrm{ppm}$ in the ${ }^{13} \mathrm{C}\left\{{ }^{1} \mathrm{H}\right\}$ NMR spectrum and a single silicon 
environment is found in the ${ }^{29} \mathrm{Si}$ NMR spectrum at $-8.3 \mathrm{ppm}$. Being void of useful IR spectroscopic handles, the IR spectrum is not particularly informative. These data, together with the elemental analyses are consistent with the proposed formulation of $\mathbf{3}$, though we note the carbon analyses of $\mathbf{3}$ are consistently low, which is a common feature with organosilyl-rich complexes due to incomplete combustion and $\mathrm{SiC}$ formation [65]. The formation of $\mathbf{3}$ implies concomitant formation of MeImCH${ }_{2} \mathrm{CH}_{2} \operatorname{ImMe}$, which is discussed below.

\subsection{Structural Characterisation of $\left[T h\left(\eta^{5}-C p^{\prime \prime}\right)_{3}(M e)\right](3)$}

In order to confirm the formulation of $\mathbf{3}$ we determined its structure by single crystal X-ray diffraction and the resulting solid state molecular structure is illustrated in Figure 3, with selected bond lengths and angles compiled in Table 1. The salient feature of $\mathbf{3}$ is the presence of three cyclopentadienyl rings, each $\eta^{5}$-coordinated, and the methyl group which resides in the pocket that is formed from the 'picket-fence' arrangement of the silyl-groups above and below the thorium ion. The thorium centre in 3 is situated $0.2750(11) \AA$ out of the plane defined by the three $\mathrm{Cp}^{\prime \prime}$ centroids, which is similar to that seen previously for $\left[\mathrm{Th}\left(\eta^{5}-\mathrm{Cp}^{\prime \prime}\right)_{3}(\mathrm{Cl})\right]($ deviation $=0.451(2) \AA)[72]$; this is closer to a trigonal pyramidal rather than a distorted tetrahedral geometry. In accord with the spectroscopic characterisation data, refining the methyl group as a hydroxide or fluoride led to substantially worse models with unrealistic displacement parameters. The $\mathrm{Th}{ }^{\cdots} \mathrm{C} \mathrm{p}_{\text {centroid }}$ distances average 2.570(4) $\AA$ in 3 (range: $2.569(3)-2.575(2) \AA$ ), which compares to $2.519(2) \AA$ (range: 2.5166(11)-2.5212(10) $\AA$ ) in $\mathbf{1}$ [51,61], consistent with the formal oxidation to a tetravalent state in 3 compared to trivalent in $\mathbf{1}$. The Th- $\mathrm{C}_{\mathrm{Me}}$ distance is $2.477(5) \AA$, which is comparable to mean Th$\mathrm{C}_{\mathrm{Me}}$ distances of $2.479(3) \AA$ in $\left[\mathrm{Th}\left(\eta^{5}-\mathrm{Cp}^{\mathrm{ttt}}\right)_{2}(\mathrm{Me})_{2}\right]\left(\mathrm{Cp}^{\mathrm{ttt}}=\mathrm{C}_{5} \mathrm{H}_{2}-1,2,4{ }^{\mathrm{t}} \mathrm{Bu}_{3}\right), 2.542(5) \AA$ in $\left[\mathrm{Th}\left(\eta^{5}-\right.\right.$ $\left.\left.\mathrm{Cp}^{\mathrm{tt}}\right)_{2}(\mathrm{Me})_{2}\right]\left(\mathrm{Cp}^{\mathrm{tt}}=\mathrm{C}_{5} \mathrm{H}_{3}-1,3-{ }^{\mathrm{t}} \mathrm{Bu}_{2}\right), 2.475(12) \AA$ in $\left[\mathrm{Th}\left(\eta^{5}-\mathrm{Cp}^{*}\right)_{2}(\mathrm{Me})_{2}\right]\left(\mathrm{Cp}^{*}=\mathrm{C}_{5} \mathrm{Me}_{5}\right)$ and 2.497(2) $\AA$ in $\left[\mathrm{Th}\left(\eta^{5}-\mathrm{Cp}^{\mathrm{Me} 4}\right)_{2}(\mathrm{Me})_{2}\right]\left(\mathrm{Cp}^{\mathrm{Me} 4}=\mathrm{C}_{5} \mathrm{HMe}_{4}\right)[73-75]$ 


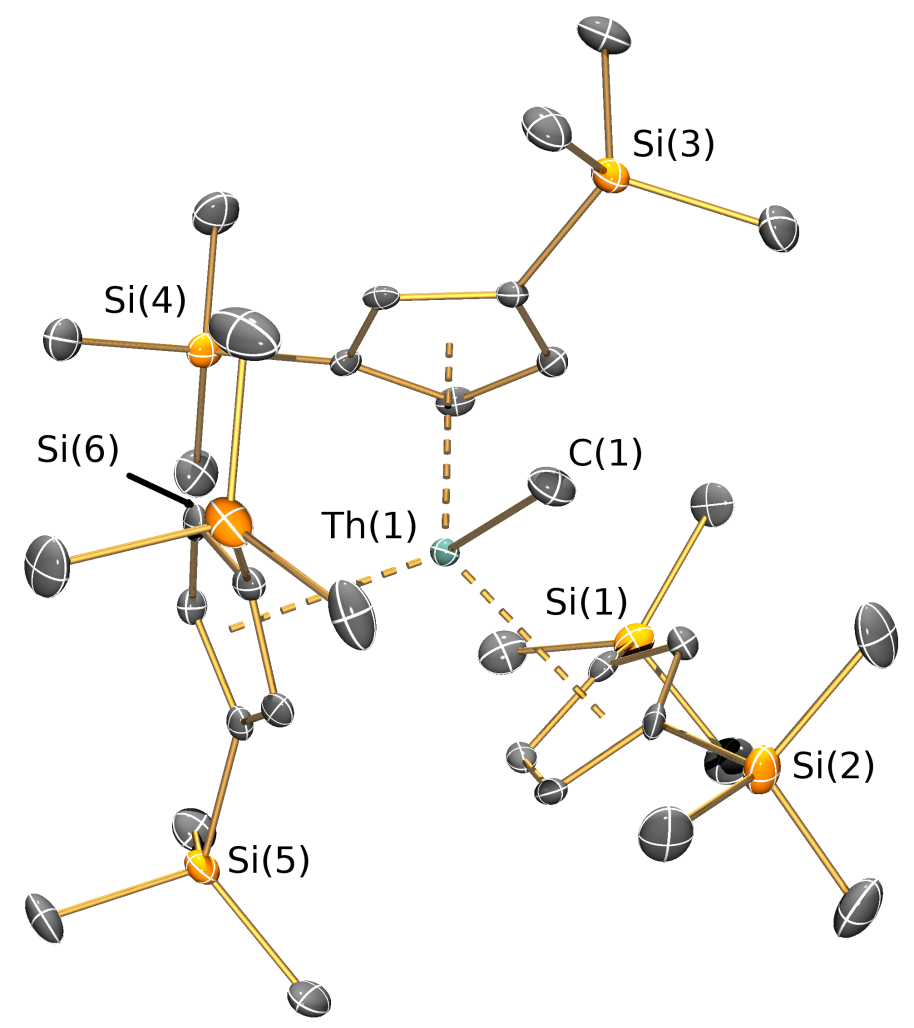

Figure 3. Molecular structure of $\mathbf{3}$ with selective atom labeling, with displacement ellipsoids set at the $30 \%$ probability level; hydrogen atoms have been omitted for clarity. 
Table 1. Selected bond distances $(\AA)$ and angles $\left({ }^{\circ}\right)$ for 3 .

\begin{tabular}{|c|c|c|c|}
\hline $\operatorname{Th}(1)-C(1)$ & $2.477(5)$ & $\operatorname{Th}(1)-\mathrm{C}(2)$ & $2.848(5)$ \\
\hline $\operatorname{Th}(1)-\mathrm{C}(3)$ & $2.863(5)$ & $\operatorname{Th}(1)-\mathrm{C}(5)$ & $2.799(5)$ \\
\hline $\operatorname{Th}(1)-\mathrm{C}(6)$ & $2.779(5)$ & $\operatorname{Th}(1)-C(15)$ & $2.854(5)$ \\
\hline $\operatorname{Th}(1)-\mathrm{C}(16)$ & $2.791(4)$ & $\operatorname{Th}(1)-C(17)$ & $2.812(5)$ \\
\hline $\mathrm{Th}(1)-\mathrm{C}(25)$ & $2.855(5)$ & $\operatorname{Th}(1)-\mathrm{C}(26)$ & $2.859(5)$ \\
\hline $\operatorname{Th}(1)-C(27)$ & $2.785(5)$ & $\operatorname{Th}(1)-\mathrm{C}(28)$ & $2.800(5)$ \\
\hline Th.•C $\mathrm{Cp}_{\text {centroid }}$ & $2.569(3)$ & 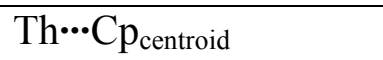 & $2.569(2)$ \\
\hline $\mathrm{Th} \cdots \mathrm{Cp}_{\text {centroid }}$ & $2.575(2)$ & $\mathrm{Cp}_{\text {centroid }}{ }^{\cdots} \mathrm{Th}(1) \cdots \mathrm{C}_{\mathrm{Me}}$ & $97.82(13)$ \\
\hline $\mathrm{C} p_{\text {centroid }} \cdots \mathrm{Th}(1) \cdots \mathrm{Cp}_{\text {centroid }}$ & $117.49(8)$ & $\mathrm{Cp}_{\text {centroid }}{ }^{\cdots} \mathrm{Th}(1) \cdots \mathrm{C}_{\mathrm{Me}}$ & $97.61(14)$ \\
\hline $\mathrm{C} \mathrm{p}_{\text {centroid }} \cdots \mathrm{Th}(1) \cdots \mathrm{Cp}_{\text {centroid }}$ & $118.69(8)$ & $\mathrm{Cp}_{\text {centroid }}{ }^{\cdots} \cdot \mathrm{Th}(1) \cdots \mathrm{C}_{\mathrm{Me}}$ & $99.17(14)$ \\
\hline $\mathrm{Cp}_{\text {centroidd }} \cdots \mathrm{Th}(1) \cdots \mathrm{Cp}_{\text {centroid }}$ & $117.83(8)$ & & \\
\hline
\end{tabular}


Table 2. Experimental X-ray crystallographic details for 3.

\begin{tabular}{|c|c|}
\hline Formula & $\mathrm{C}_{34} \mathrm{H}_{66} \mathrm{Si}_{6} \mathrm{Th}$ \\
\hline Fw & 875.44 \\
\hline Cryst size, $\mathrm{mm}^{3}$ & $0.233 \times 0.211 \times 0.195$ \\
\hline Cryst syst & Monoclinic \\
\hline Space group & $P 2_{1} / \mathrm{n}$ \\
\hline Collection Temperature & $150(2)$ \\
\hline $\mathrm{a}, \AA$ & $13.1182(4)$ \\
\hline $\mathrm{b}, \AA$ & $19.0794(7)$ \\
\hline $\mathrm{c}, \AA$ & $17.7625(5)$ \\
\hline$\alpha,{ }^{\circ}$ & \\
\hline$\beta, \circ$ & $91.051(3)$ \\
\hline$\gamma,{ }^{\circ}$ & \\
\hline $\mathrm{V}, \AA^{3}$ & $4445.0(2)$ \\
\hline Z & 4 \\
\hline$\rho_{\text {calc }} \mathrm{g} \mathrm{cm}-^{3}$ & 1.308 \\
\hline$\mu, \mathrm{mm}^{-1}$ & 3.536 \\
\hline no. of reflections measd & 17168 \\
\hline no. of unique reflns, Rint & $8122,0.0475$ \\
\hline no. of reflns with $F^{2}>2 \mathrm{~s}\left(F^{2}\right)$ & 6334 \\
\hline transmn coeff range & $0.58-0.62$ \\
\hline$R, R_{\mathrm{w}}{ }^{a}\left(F^{2}>2 \mathrm{~s}\left(F^{2}\right)\right)$ & $0.0457,0.0643$ \\
\hline$R, R_{\mathrm{w}}{ }^{a}$ (all data) & $0.0660,0.0718$ \\
\hline$S^{\mathrm{a}}$ & 1.029 \\
\hline Parameters & 370 \\
\hline max.,min. diff map, e $\AA^{-3}$ & $0.868,-0.639$ \\
\hline
\end{tabular}


a)

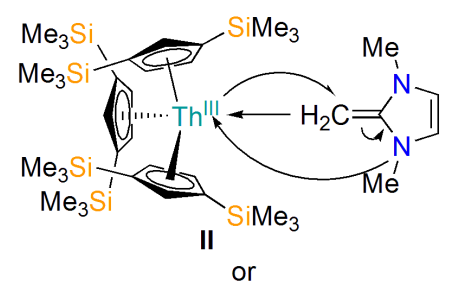

b)
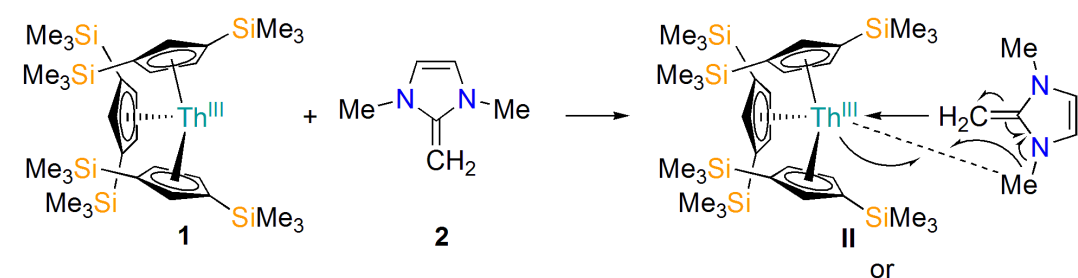

c)
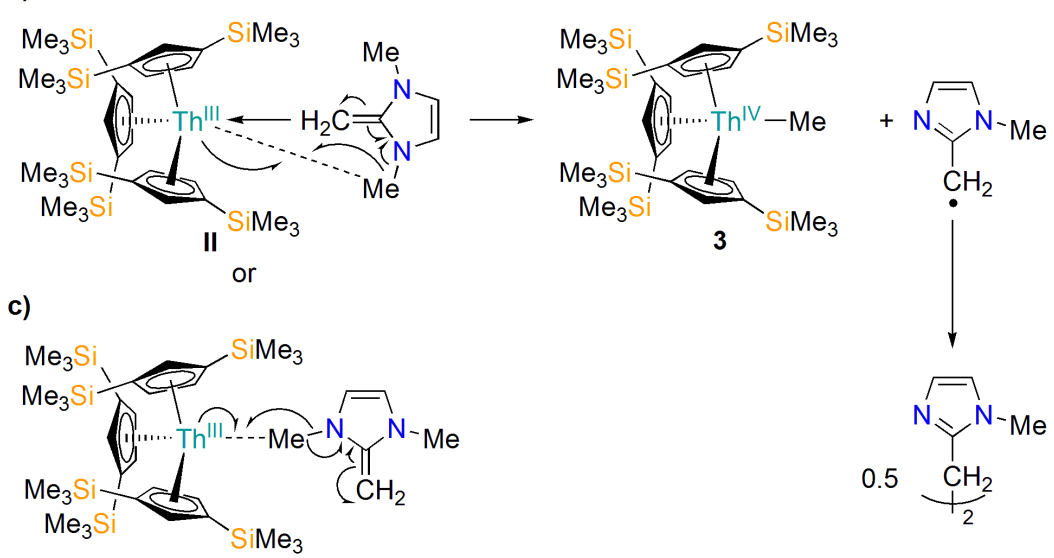

Scheme 2. Proposed possible mechanisms for the formation of $\mathbf{3}$ from the reaction of $\mathbf{1}$ with $\mathbf{2}$.

The reaction that produces 3 raises the question as to a likely mechanism that accounts for provision of a methyl group at thorium and the oxidation of thorium(III) in $\mathbf{1}$ to thorium(IV) in $\mathbf{3}$. Three credible routes can be proposed, Scheme 2, each of which would be consistent with the fact that no obvious reaction was observed between $\mathbf{1}$ and $\mathbf{2}$ at room temperature. In route a), thermolysis could assist in opening up the coordination sphere of $\mathbf{1}$ to allow $\mathbf{2}$ to coordinate. This would poise the coordinated alkene unit to be subjected to a one electron reduction from the highly reducing thorium(III). It follows that this could ultimately lead to attack at thorium by the $N$-methyl to result in the formation of $\mathbf{3}$. In the closely related mechanism b), coordination of the NHO to thorium would bring the $N$-methyl group into close proximity of the reducing thorium(III) ion, with two one-electron transfers forming a new Th-Me bond. In both cases concomitant electron transfer would produce a MeIm-radical. Alternatively, given the apparent need for thermal activation, it could be that path c) operates where the reducing thorium(III) centre could directly activate the $N$ - 
methyl bond, again resulting in formation of the MeIm-radical, but in this scenario pre-coordination of the NHO to thorium is not required. In all three scenarios the MeIm-radical would be anticipated to couple of produce $\mathrm{MeImCH}_{2} \mathrm{CH}_{2} \mathrm{ImMe}$.

In order to probe the reaction mechanism further we mixed $\mathbf{1}$ and $\mathbf{2}$ together in $\mathrm{D}_{8}$-toluene and assayed the mixture by periodically recording and examining its ${ }^{1} \mathrm{H}$ NMR spectrum. After mixing, the blue colour of $\mathbf{1}$ is retained, however the resulting NMR spectrum suggests that $\mathbf{2}$ is coordinated to $\mathbf{1}$ to give II; the methyl resonance of the NHO is shifted slightly from $2.5 \mathrm{ppm}$, in the free form, to $2.45 \mathrm{ppm}$, and the methylene protons, originally a singlet at $2.75 \mathrm{ppm}$, now resonate as a diastereotopic pair at 2.65 and $3.25 \mathrm{ppm}$. Additionally, like the methylene protons, the normally equivalent alkene-type hydrogens from the backbone of the NHO are now split and shifted from 5.45 to 5.8 and $5.9 \mathrm{ppm}$, suggesting that they are now inequivalent by symmetry, and this in addition to shifts relative to the free NHO suggests coordination to thorium. However, a small quantity (ca 15\%) of free NHO can still be observed after mixing suggesting that an equilibrium is established between free- and coordinated-NHO, with the latter being favoured. Heating this mixture to $130{ }^{\circ} \mathrm{C}$ results in gradual consumption of II as $\mathbf{3}$ grows in, though unreacted $\mathbf{2}$ and decomposition products are also present in the reaction mixture. Unfortunately, the deposition of some solid during this time, along with decomposition of 1 under these harsh conditions means reliable kinetic data could not be obtained due to a varying concentration over time. After $18 \mathrm{hrs,} 3$ is the majority product along with an organic compound, which exhibits principal resonances at 2.8 ppm (assigned as $\mathrm{N}$-methyl), two broad multiplets at 3.3 and $3.7 \mathrm{ppm}$ (assigned as diastereotopic methylene hydrogens from an ethyl bridge) and 5.8 and $6.1 \mathrm{ppm}$ indicating inequivalent $\mathrm{NHO}$ backbone hydrogens (Supplementary Materials Figure S1). The inequivalence of the backbone hydrogens is consistent with $N$-demethylation and also the formation of a symmetric ethyl bridge between two coupled MeIm-units to give $\mathrm{MeImCH}_{2} \mathrm{CH}_{2} \mathrm{ImMe}$, Scheme 2, since any asymmetric functionalisation of the MeIm-units would lead to more individual alkene-type resonances. Though 
we did not isolate it, support for the proposal that $\mathrm{MeImCH}_{2} \mathrm{CH}_{2} \mathrm{ImMe}$ is the co-product to 3 from the reaction of $\mathbf{1}$ with $\mathbf{2}$ is provided by mass spectrometry, where in negative mode electrospray ionisation the parent ion $\left\{\mathrm{MeImCH}_{2} \mathrm{CH}_{2} \mathrm{ImMe}^{-}\right.$is observed at $\mathrm{m} / \mathrm{z} 190.1$. Thus, spectroscopic monitoring of the reaction yields observations that are consistent with coordination of $\mathbf{2}$ to $\mathbf{1}$ to give II, which reacts in a thermal regime to give 3. On this basis we favour path b) since it invokes II as an intermediate and best accounts for cleavage of the $N$-methyl bond, though this does not completely rule out path a), and path c) cannot be unequivocally ruled out due to the equilibrium of free- and coordinated-NHO. Each route would be consistent with the thermally promoted nature of the reaction, and the strongly reducing nature of thorium(III), and it is noteworthy that $\mathbf{1}$ has previously been shown to reduce substrates where even strongly reducing trivalent uranium tris(cyclopentadienyl) complexes cannot. For example, pyridine and 4,4'-bipyridine are activated by $\mathbf{1}$ but not by the uranium(III) analogue [63], and when 2 is reacted with the less reducing uranium(III) complex $\left[\mathrm{U}\left\{\mathrm{N}\left(\mathrm{SiMe}_{3}\right)_{2}\right\}_{3}\right]$ the 'abnormal' uranium(III) mesoionic carbene complex $\left[\mathrm{U}\left\{\mathrm{N}\left(\mathrm{SiMe}_{3}\right)_{2}\right\}_{3}\{\mathrm{CN}(\mathrm{Me}) \mathrm{C}(\mathrm{Me}) \mathrm{N}(\mathrm{Me}) \mathrm{C}(\mathrm{H})\}\right]$ is formed with no evidence of $N$-methyl cleavage [76].

\section{Conclusions}

To conclude, we have reported on the reactivity of an $N$-heterocyclic olefin with a tris(cyclopentadienyl) thorium(III) complex at elevated temperature. The result is $N$-methyl cleavage to give a tris(cyclopentadienyl) thorium(IV)-methyl complex along with an organic product that, on the basis of spectroscopic characterisation, we suggest is $\mathrm{MeImCH}_{2} \mathrm{CH}_{2} \operatorname{ImMe}$. This work highlights the highly reactive nature of redox-active thorium(III), and also alludes to the challenges of constructing alkylidene-like functionality at large and electropositive ions such as thorium. 


\section{Acknowledgements}

We thank the Engineering and Physical Sciences Research Council (Grant numbers EP/P002560/1 and EP/M027015/1; Nuclear FiRST studentship for A.F.), European Research Council (CoG612724), the China Scholarship Council (studentship for J.L.) and The University of Manchester for funding this work. Additional research data supporting this publication are available from Mendeley Data at 10.17632/j7ms5hfdyj.1.

\section{Conflicts of interest}

The authors declare no competing financial interest.

\section{Appendix A. Supplementary data}

CCDC 1560927 contains the supplementary crystal data for this article. These data can be obtained free of charge from the Cambridge Crystallographic Data Centre via www.ccdc.cam.ac.uk/data_request/cif.. Supplementary data associated with this article can be found, in the online version, at XXXXX.

\section{References}

[1] S.T. Liddle, Angew. Chem. Int. Ed. 54 (2015) 8604-8641.

[2] M. Gregson, A.J. Wooles, O.J. Cooper, S.T. Liddle, Comments on Inorganic Chemistry 35 (2015) 262-294.

[3] M. Ephritikhine, Comptes Rendus Chimie, 16 (2013) 391-405.

[4] T.W. Hayton, Chem. Commun. 49 (2013) 2956-2973.

[5] T.W. Hayton, Dalton Trans. 39 (2010) 1145-1158. 
[6] M. Ephritikhine, Dalton Trans. (2006) 2501-2516.

[7] R.E. Cramer, R.B. Maynard, J.C. Paw, J.W. Gilje, J. Am. Chem. Soc. 103 (1981) 3589-3590.

[8] R.E. Cramer, R.B. Maynard, J.C. Paw, J.W. Gilje, Organometallics 1 (1982) 869-871.

[9] R.E. Cramer, J.H. Jeong, P.N. Richmann, J.W. Gilje, Organometallics 9 (1990) 1141-1146.

[10] R.E. Cramer, J.H. Jeong, J.W. Gilje, Organometallics 5 (1986) 2555-2557.

[11] R.E. Cramer, K.T. Higa, J.W. Gilje, J. Am. Chem. Soc. 106 (1984) 7245-7247.

[12] R.E. Cramer, K.T. Higa, S.L. Pruskin, J.W. Gilje, J. Am. Chem. Soc. 105 (1983) 6749-6750.

[13] R.E. Cramer, K. Panchanatheswaran, J.W. Gilje, Angew. Chem., Int. Ed. 23 (1984) 912-913.

[14] R.E. Cramer, K. Panchanatheswaran, J.W. Gilje, J. Am. Chem. Soc. 106 (1984) 1853-1854.

[15] R.E. Cramer, U. Engelhardt, K.T. Higa, J.W. Gilje, Organometallics 6 (1987) 41-45.

[16] R.C. Stevens, R. Bau, R.E. Cramer, D. Afzal, J.W. Gilje, T.F. Koetzle, Organometallics 9 (1990) 694-697.

[17] T. Cantat, T. Arliguie, A. Noël, P. Thuéry, M. Ephritikhine, P. Le Floch. N. Mézailles, J. Am. Chem. Soc. 131 (2009) 963-972.

[18] J.C. Tourneux, J.C. Berthet, P. Thuéry, N. Mézailles, P. Le Floch, M. Ephritikhine, Dalton Trans. 39 (2010) 2494-2496.

[19] O.J. Cooper, J. McMaster, W. Lewis, A.J. Blake, S.T. Liddle, Dalton Trans. 39 (2010) 50745076.

[20] J.C. Tourneux, J.C. Berthet, T. Cantat, P. Thuéry, N. Mézailles, P. Le Floch, M. Ephritikhine, Organometallics 30 (2011) 2957-.

[21] J.C. Tourneux, J.C. Berthet, T. Cantat, P. Thuéry, N. Mézailles, M. Ephritikhine, J. Am. Chem. Soc. 133 (2011) 6162-6165.

[22] D.P. Mills, F. Moro, J. McMaster, J. van Slageren, W. Lewis, A.J. Blake, S.T. Liddle, Nat. Chem. 3 (2011) 454-460.

[23] G.B. Ma, M.J. Ferguson, R. McDonald, R.G. Cavell, Inorg. Chem. 50 (2011) 6500-6508. 
[24] O.J. Cooper, D.P. Mills, J. McMaster, F. Moro, E.S. Davies, W. Lewis, A.J. Blake, S.T. Liddle, Angew. Chem. Int. Ed. 50 (2011) 2383-2386.

[25] S. Fortier, J.R. Walensky, G. Wu, T.W. Hayton, J. Am. Chem. Soc. 133 (2011) 6894-6897.

[26] W. Ren, X. Deng, G. Zi, D.C. Fang, Dalton Trans. 40 (2011) 9662-9664.

[27] D.P. Mills, O.J. Cooper, F. Tuna, E.J.L. McInnes, E.S. Davies, J. McMaster, F. Moro, W. Lewis, A.J. Blake, S.T. Liddle, J. Am. Chem. Soc. 134 (2012) 10047-10054.

[28] O.J. Cooper, D.P. Mills, J. McMaster, F. Tuna, E.J.L. McInnes, W. Lewis, A.J. Blake, S.T. Liddle, Chem. Eur. J. 19 (2013) 7071-7083.

[29] E. Lu, W. Lewis, A.J. Blake, S.T. Liddle, Angew. Chem. Int. Ed. 53 (2014) 9356-9359.

[30] E. Lu, O.J. Cooper, J. McMaster, F. Tuna, E.J.L. McInnes, W. Lewis, A.J. Blake, S.T. Liddle, Angew. Chem. Int. Ed. 53 (2014) 6696-6700.

[31] O.J. Cooper, D.P. Mills, W. Lewis, A.J. Blake, S.T. Liddle, Dalton Trans. 43 (2014) 1427514283.

[32] M. Gregson, E. Lu, F. Tuna, E.J.L. McInnes, C. Hennig, A.C. Scheinost, J. McMaster, W. Lewis, A.J. Blake, A. Kerridge, S.T. Liddle, Chem. Sci. 7 (2016) 3286-3297.

[33] E. Lu, F. Tuna, W. Lewis, N. Kaltsoyannis, S.T. Liddle, Chem. Eur. J. 22 (2016) 1155411558.

[34] E. Lu, O.J. Cooper, F. Tuna, A.J. Wooles, N. Kaltsoyannis, S.T. Liddle, Chem. Eur. J. 22 (2016) 11559-11563.

[35] M. Gregson, E. Lu, D.P. Mills, F. Tuna, E.J.L. McInnes, C. Hennig, A.C. Scheinost, J. McMaster, W. Lewis, A.J. Blake, A. Kerridge, S.T. Liddle, Nat. Commun. 8 (2017) 14137.

[36] D.E. Smiles, G. Wu, P. Hrobárik, T.W. Hayton, Organometallics doi:10.1021/acs.organomet.7b00202.

[37] L. Andrews, H.G. Cho, J. Phys. Chem. A 109 (2005) 6796-6798.

[38] J.T. Lyon, L. Andrews, Inorg. Chem. 44 (2005) 8610-8616.

[39] J.T. Lyon, L. Andrews, Inorg. Chem. 45 (2006) 1847-1852. 
[40] J.T. Lyon, L. Andrews, P.Å. Malmqvist, B.O. Roos, T. Yang, B.E. Bursten, Inorg. Chem. 46 (2007) 4917-4925.

[41] B.O. Roos, R. Lindh, H.G. Cho, L. Andrews, J. Phys. Chem. A 111 (2007) 6420-6424.

[42] J.T. Lyon, L. Andrews, H.S. Hu, J. Li, Inorg. Chem. 47 (2008) 1435-1442.

[43] H.G. Cho, J.T. Lyon, L. Andrews, J. Phys. Chem. A 112 (2008) 6902-6907.

[44] H.G. Cho, L. Andrews, Organometallics 31 (2012) 535-544.

[45] H.G. Cho, L. Andrews, J. Phys. Chem. A 119 (2015) 2289-2297.

[46] M.Y. He, G. Xiong, P.J. Toscano, R.L. Burwell Jr, T.J. Marks, J. Am. Chem. Soc. 107 (1985) 641-652.

[47] C. Villiers, M. Ephritikhine, Chem. Eur. J. 7 (2001) 3043-3051.

[48] A. Yahia, L. Castro, L. Maron, Chem. Eur. J. 16 (2010) 5564-5567.

[49] N.R. Paisley, M.W. Lui, R. McDonald, M.J. Ferguson, E. Rivard, Dalton Trans. 45 (2016) 9860-9870.

[50] M.M.D. Roy, E. Rivard, Acc. Chem. Res. 50 (2017) 2017-2025.

[51] P.C. Blake, M.F. Lappert, J.L. Atwood, H. Zhang, J. Chem. Soc. Chem. Commun. (1986) 1148-1149.

[52] A. Fürstner, M. Alcarazo, R. Goddard, C.W. Lehmann, Angew. Chem. Int. Ed. 47 (2008) 3210-3214.

[53] J.S. Parry, F.G.N. Cloke, S.J. Coles, M.B. Hursthouse, J. Am. Chem. Soc. 121 (1999) 68676871.

[54] P.C. Blake, N.M. Edelstein, P.B. Hitchcock, W.K. Kot, M.F. Lappert, G.V. Shalimoff, S. Tian, J. Organomet. Chem. 636 (2001) 124-129.

[55] J.R. Walensky, R.L. Martin, J.W. Ziller, W.J. Evans, Inorg. Chem. 49 (2010) 10007-10012.

[56] N.A. Siladke, C.L. Webster, J.R. Walensky, M.K. Takase, J.W. Ziller, D.J. Grant, L. Gagliardi, W.J. Evans, Organometallics 32 (2013) 6522-6531. 
[57] R.R. Langeslay, M.E. Fieser, J.W. Ziller, F. Furche, W.J. Evans, J. Am. Chem. Soc. 138 (2016) 4036-4045.

[58] F. Ortu, A. Formanuik, J.R. Innes, D.P. Mills, Dalton Trans. 45 (2016) 7537-7549.

[59] R.R. Langeslay, G.P. Chen, C.J. Windorff, A.K. Chan, J.W. Ziller, F. Furche, W.J. Evans, J. Am. Chem. Soc. 139 (2017) 3387-3398.

[60] A. Formanuik, A.M. Ariciu, F. Ortu, R. Beekmeyer, A. Kerridge, F. Tuna, E.J.L McInnes, D.P. Mills, Nat. Chem. 9 (2017) 578-583.

[61] R.R. Langeslay, M.E. Fieser, J.W. Ziller, F. Furche, W.J. Evans, Chem. Sci. 6 (2015) 517521.

[62] A. Formanuik, F. Ortu, R. Beekmeyer, A. Kerridge, R.W. Adams, D.P. Mills, Dalton Trans. 45 (2016) 2390-2393.

[63] A. Formanuik, F. Ortu, C.J. Inman, A. Kerridge, L. Castro, L. Maron, D.P. Mills, Chem. Eur. J. 22 (2016) 17976-17979.

[64] A. Formanuik, F. Ortu, J. Liu, L.E. Nodaraki, F. Tuna, A. Kerridge, D.P. Mills, Chem. Eur. J. 23 (2017) 2290-2293.

[65] P.B. Hitchcock, M.F. Lappert, L. Maron, A.V. Protchenko, Angew. Chem. Int. Ed. 47 (2008) 1488-1491.

[66] P. Coppens, W.C. Hamilton, Acta Cryst. Sect. A A26 (1970) 71-83.

[67] G.M. Sheldrick, Acta Cryst. Sect. C C71 (2015). 3-8, G.M. Sheldrick, Acta Cryst. Sect. A A64 (2008). 112-122.

[68] CrysAlisPRO, Oxford Diffraction /Agilent Technologies UK Ltd, Yarnton, England (2010).

[69] O.V. Dolomanov, L.J. Bourhis, R.J. Gildea, J.A.K. Howard, H. Puschmann, J. Appl. Cryst. 42 (2009) 339-341.

[70] L.J. Farugia, J. Appl. Cryst.45 (2012) 849-854.

[71] Persistence of Vision (TM) Raytracer, Persistence of Vision Pty. Ltd., Williamstown, Victoria, Australia (2004). 
[72] P.C. Blake, M.A. Edelman, P.B. Hitchcock, J. Hu, M.F. Lappert, S. Tian, G. Müller, J.L. Atwood, H. Zhang, J. Organomet. Chem. 551 (1998) 261-270.

[73] W. Ren, G. Zi, D.C. Fang, M.D. Walter, Chem. Eur. J. 17 (2011) 12699-12682.

[74] K.C. Jantunen, C.J. Burns, I. Castro-Rodriguez, R.E. Da Re, J.T. Golden, D.E. Morris, B.L. Scott, F.L. Taw, J.L. Kiplinger, Organometallics 23 (2004) 4682-4692.

[75] N.A. Siladke, C.L. Webster, J.R. Walensky, M.K. Takase, J.W. Ziller, D.J. Grant, L. Gagliardi, W.J. Evans, Organometallics 32 (2013) 6522-6531.

[76] J.A. Seed, M. Gregson, F. Tuna, N.F. Chilton, A.J. Wooles, E.J.L. McInnes, S.T.Liddle, Angew. Chem. Int. Ed. 56 (2017) DOI:10.1002/anie.201706546.

\section{ToC Entry}

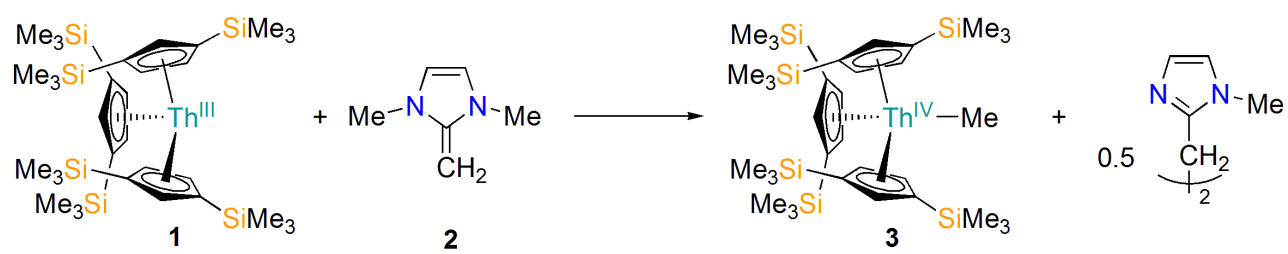

Surprisingly, treatment of $\mathbf{1}$ with $\mathbf{2}$ results in $N$-methyl cleavage and oxidation of thorium to give $\mathbf{3}$. 